\title{
Integrated Fossil Fuel and Solar Thermal Systems for Hydrogen Production and $\mathrm{CO}_{2}$ Mitigation
}

\author{
Zhaolin Wang ${ }^{1}$, Greg F. Naterer ${ }^{2}$ \\ ${ }^{1}$ Clean Energy Research Laboratory, University of Ontario Institute of Technology, \\ Oshawa, Ontario, L1H 7K4, Canada \\ ${ }^{2}$ Faculty of Engineering and Applied Science, Memorial University of Newfoundland, \\ St. John's, Newfoundland, A1B 3X5, Canada \\ Email: zhaolin.wang@uoit.ca,gnaterer@mun.ca
}

\begin{abstract}
:
In most current fossil-based hydrogen production methods, the thermal energy required by the endothermic processes of the hydrogen production process is supplied by the combustion of a portion of the same fossil fuel feedstock. This increases the fossil fuel consumption and greenhouse gas emissions. This paper analyzes the thermodynamics of several typical fossil fuel-based hydrogen production methods such as steaam methane reforming, coal gasification, methane dissociation, and off-gas reforming, to quantify the potential savings of fossil fuels and $\mathrm{CO}_{2}$ emissions associated with the thermal energy requirement. Then matching the heat quality and quantity by solar thermal energy for different processes is examined. It is concluded that steam generation and superheating by solar energy for the supply of gaseous reactants to the hydrogen production cycles is particularly attractive due to the engineering maturity and simplicity. It is also concluded that steam-methane reforming may have fewer engineering challenges because of its single-phase reaction, if the endothermic reaction enthalpy of syngas production step ( $\mathrm{CO}$ and $\mathrm{H}_{2}$ ) of coal gasification and steam methane reforming is provided by solar thermal energy. Various solar thermal energy based reactors are discussed for different types of production cycles as well.
\end{abstract}

Keywords: hydrogen production, solar energy, fossil fuels, $\mathrm{CO}_{2}$ reduction.

\footnotetext{
${ }^{1}$ Corresponding author

Zhaolin Wang, Clean Energy Research Laboratory, University of Ontario Institute of Technology, 2000 Simcoe St N, Oshawa, Ontario, L1H 7K4, Canada zhaolin.wang@uoit.ca 1-905-721-8668 ext 3478
} 


\section{Introduction}

The demand for energy is continuing to rise rapidly as the world aims to improve its standard of living. Due to their environmental impact, the current utilization of carbon-based fuels is unsustainable. To establish a sustainable energy future is one of the most pressing challenges of mankind. Hydrogen is viewed widely as a promising alternative of fossil fuels for the future. For example, it was reported that the efficiency of a hydrogen internal combustion engine could be $10-40 \%$ higher than a gasoline engine. The hybrid electric motor and fuel cell vehicle could even be 2 - 3 times more efficient than an internal gasoline combustion engine [1]. As hydrogen-based fuel cells are developed to convert the oxidation of hydrogen to electricity, future vehicles could be fully electrified by using hydrogen. Hydrogen is also a very useful commercial product for conventional petroleum processing in the upgrading of long chain hydrocarbons. Also, hydrogen is a necessity for the production of fertilizers in the agricultural industry. Currently, heavy oil upgrading and ammonia-based fertilizer production account for about $50 \%$ and $40 \%$ of the current hydrogen production, respectively [2-4]. The rising need of hydrogen by modern agriculture and petroleum products is also expected to strongly advance the hydrogen economy [5, 6].

However, a future hydrogen economy may hardly make sense unless renewable or "green” content is significantly improved for current hydrogen production methods. There are a number of renewable hydrogen production methods under development, such as nuclear and solar-based high temperature electrolysis and thermochemical water splitting cycles [7-11]. However, the large-scale adoption of these methods is not yet ready for commercialization. Conventional water electrolysis only accounts for less than $4 \%$ of the total world hydrogen production, while more than $95 \%$ of the global hydrogen is produced from fossil fuels, i.e., 48\% from steam methane reforming (SMR), 30\% from refinery / chemical off-gases, and 18\% from coal gasification [12, 13].

To improve the renewable degree of fossil fuel-based hydrogen production, an option is to utilize solar energy to provide the processing heat that is currently supplied by the combustion of a portion of the fossil fuels. This paper will analyze the thermodynamics of several typical fossil fuel-based hydrogen production methods to examine the challenges and feasibility of utilizing solar energy for the processing 
heat supply so as to replace the burning of fossil fuels. It is expected that the analysis could provide new insights and information for the hydrogen industry to mitigate the $\mathrm{CO}_{2}$ emissions and at the same time save a large amount of valuable fossil fuels. $\mathrm{CO}_{2}$ mitigation and potential fossil fuel savings resulting from the usage of solar energy will be quantified for most primary fossil fuel-based hydrogen production methods including steam-methane reforming, methane dissociation, and coal gasification. Also, matching of process heat quality and quantity by current and potential solar thermal energy technologies will be examined for different hydrogen production methods. Typical reactor and auxiliary heat transfer structures will be compared for different processes in different hydrogen production cycles. Finally, the layout of equipment and heat flows will also be discussed for both single and multiphase processes.

\section{Solar-based steam methane reforming}

As discussed previously, currently $48 \%$ of the total hydrogen production is obtained from steam methane reforming (SMR), which emits large amounts of $\mathrm{CO}_{2}$ emissions. An option for a "greener" SMR process is to use solar thermal energy to replace the heat supplied by the combustion of methane. A typical SMR process includes two steps [14-16]:

1) Syngas production:

$\mathrm{CH}_{4}(\mathrm{~g})+\mathrm{H}_{2} \mathrm{O}(\mathrm{g})=\mathrm{CO}(\mathrm{g})+3 \mathrm{H}_{2}(\mathrm{~g})$, at $800-1,000^{\circ} \mathrm{C}, \Delta \mathrm{H}^{\circ}=206.25 \mathrm{~kJ} / \mathrm{mol}$, reaction (1)

2) Water gas shift reaction:

$\mathrm{CO}(\mathrm{g})+\mathrm{H}_{2} \mathrm{O}(\mathrm{g})=\mathrm{CO}_{2}(\mathrm{~g})+\mathrm{H}_{2}(\mathrm{~g})$ at $350-452^{\circ} \mathrm{C}, \Delta \mathrm{H}^{\mathrm{o}}=-41.03 \mathrm{~kJ} / \mathrm{mol}$, reaction (2)

The overall reaction is:

$\mathrm{CH}_{4}(\mathrm{~g})+2 \mathrm{H}_{2} \mathrm{O}(\mathrm{g})+\mathrm{CO}_{2}(\mathrm{~g})+4 \mathrm{H}_{2}(\mathrm{~g}), \quad$ reaction

(3)

Reaction (1) is an endothermic process requiring heat input. In the reaction, the mixture of methane and steam reacts on the surface of catalysts at a temperature level between 800 and $1,000^{\circ} \mathrm{C}$ [14]. 
The factors influencing the conversion rate include the temperatures and residence time of the gas mixture. Reaction (2) is a slightly exothermic process, thus the hydrogen yield increases with decreasing the process temperature at the cost of lowering the reaction rate. The optimal temperature range is between 350 and $420^{\circ} \mathrm{C}$ [15]. Therefore, the CO gas produced in step (1) must be cooled down significantly to fit the temperature of reaction (2).

As the heat requirement of reaction (1) is much larger than the heat released by reaction (2), additional heat must be supplied to sustain reaction (1). Apart from the reaction heat, the water must be evaporated and preheated to the reaction temperature. Currently, the heat is supplied by the combustion of an extra amount of methane:

$$
\mathrm{CH}_{4}(\mathrm{~g})+\mathrm{H}_{2} \mathrm{O}(\mathrm{g})+\mathrm{X}\left[\mathrm{CH}_{4}(\mathrm{~g})+2 \mathrm{O}_{2}(\mathrm{~g})\right]==\mathrm{CO}_{2}(\mathrm{~g})+\mathrm{H}_{2}(\mathrm{~g})+\mathrm{X}\left[\mathrm{CO}_{2}(\mathrm{~g})+2 \mathrm{H}_{2} \mathrm{O}(\mathrm{g})\right] \text {, reaction (4) }
$$

where $\mathrm{X}$ represents the extra amount of methane to be combusted, as well as the extra $\mathrm{CO}_{2}$ emissions. If the combusted methane can be replaced with solar energy, then $\mathrm{CO}_{2}$ emissions can be eliminated and a portion of methane can be saved. To estimate the extra amount, table 1 lists the thermal energy balance for the heat input and output of the reactions and auxiliary steps. It can be observed that the external heat required to complete the reforming loop of methane is $252.81 \mathrm{~kJ} / \mathrm{mol}$. Compared with the combustion heat of methane, i.e., $802.31 \mathrm{~kJ} / \mathrm{mol}$, at least an additional 0.315 mole of methane is needed for the external heat requirement of the SMR process, provided that the heat losses to the environment are neglected. If this heat is replaced with solar thermal energy, then the $\mathrm{CO}_{2}$ emissions can be decreased by 0.315 moles, which are equivalent to a $24 \%$ reduction of $\mathrm{CO}_{2}$ emissions from the SMR process.

\section{Solar-based methane decarbonization}

Another methane-based hydrogen production method is the thermal dissociation of methane to produce hydrogen and high value carbon black. This process is also called "methane decarbonization" [17-21]. The dissociation reaction is given as follows:

$\mathrm{CH}_{4}(\mathrm{~g})=\mathrm{C}(\mathrm{s})+2 \mathrm{H}_{2}(\mathrm{~g})$, at $800-1,900{ }^{\circ} \mathrm{C}, \Delta \mathrm{H}^{\circ}=74.9 \mathrm{~kJ} / \mathrm{mol}$, reaction (5) 
Currently in most methane dissociation plants, the decomposition heat is provided by the combustion of an extra amount of methane:

$\mathrm{CH}_{4}(\mathrm{~g})+\mathrm{X}\left[\mathrm{CH}_{4}(\mathrm{~g})+2 \mathrm{O}_{2}(\mathrm{~g})\right]=\mathrm{C}(\mathrm{s})+2 \mathrm{H}_{2}(\mathrm{~g})+\mathrm{X}\left[\mathrm{CO}_{2}(\mathrm{~g})+2 \mathrm{H}_{2} \mathrm{O}(\mathrm{g})\right]$, reaction (6)

A challenge of estimating the extra methane needed for the dissociation is that the operating temperature range of reactions (5) and (6) is large, so the heat that can be recovered from high temperature products for the preheating of methane depends on the operating temperature. Some investigations show that the conversion of methane to carbon black increases with increasing temperature [17-19]. A value close to $100 \%$ has been observed when the temperature is higher than $1,900^{\circ} \mathrm{C}$ [17]. In this paper, the heat recovery is calculated on the basis of $1,900{ }^{\circ} \mathrm{C}$, as shown in table 2 . It can be observed that the heat released from the cooling of the two products (hydrogen and carbon black) can cover the preheating of the methane reactant, either in terms of heat quantity or quality.

However, the recovered heat cannot be used to supply the reaction enthalpy, because the temperature of the reaction is at the highest level in all relevant processes. So instead of using the net heat quantity $(18.0 \mathrm{~kJ} / \mathrm{mol})$ obtained from all temperatures, the heat requirement $(74.9 \mathrm{~kJ} / \mathrm{mol})$ at $1,900{ }^{\circ} \mathrm{C}$ should be used to calculate the extra amount of methane to be burned. The calculation is listed in table 2 . It can be found that the extra methane needed for combustion is about 0.093 mole for the decomposition of 1 mole of methane, i.e., $\mathrm{X}=0.093$ in reaction (6). This suggests that the $\mathrm{CO}_{2}$ emissions can be reduced by about $8.5 \%$ if such a heat requirement is replaced with solar thermal energy.

\section{Solar-based reforming of refinery off-gases and coal gasification}

As for the steam reforming and decarbonization of refinery off-gases, it occupies about $30 \%$ of the total hydrogen production in nowadays. The intake could be gas or liquid and the processes are more similar to steam methane reforming compared with coal gasification [22, 23], so the details of the reforming of off-gases won't be discussed in this paper. At present, coal gasification is another conventional hydrogen production method that occupies about $18 \%$ of the total hydrogen production. The process is represented by reaction (2) (water gas shift reaction) and the following reaction. 
Carbon monoxide production:

$\mathrm{H}_{2} \mathrm{O}(\mathrm{g})+\mathrm{C}(\mathrm{s})=\mathrm{CO}(\mathrm{g})+\mathrm{H}_{2}(\mathrm{~g})$, at $800-1,500^{\circ} \mathrm{C}, \Delta \mathrm{H}^{\circ}=135.75 \mathrm{~kJ} / \mathrm{mol}$, reaction (7)

Since the generation of steam also requires heat, the coal gasification process can be represented by the following overall reaction:

$2 \mathrm{H}_{2} \mathrm{O}(\mathrm{l})+\mathrm{C}=\mathrm{CO}_{2}+2 \mathrm{H}_{2}, \Delta \mathrm{H}^{0}=178.12 \mathrm{~kJ} / \mathrm{mol}$, reaction (8)

where the liquid form indicates the need of evaporation. If the heat is provided by the combustion of an extra amount of carbon, then reaction (8) is rewritten as:

$2 \mathrm{H}_{2} \mathrm{O}(\mathrm{l})+\mathrm{C}+\mathrm{X}\left(\mathrm{C}+\mathrm{O}_{2}\right)=\mathrm{CO}_{2}+2 \mathrm{H}_{2}+\mathrm{X} \mathrm{CO}_{2}(\mathrm{~g})$, reaction (9)

Then from the reaction enthalpy of reaction (8) $(178.12 \mathrm{~kJ} / \mathrm{mol})$ and the combustion heat of carbon (393.52 kJ/mol), the value of $\mathrm{X}$ is 0.453 moles. Thus, if the solar heat is used to replace the combustion of carbon, the $\mathrm{CO}_{2}$ emissions for the gasification of 1 mole of carbon can be lowered from 1.453 moles to 1 mole, i.e., the reduction percentage is about $31 \%$, which is a significant decrease.

\section{Matching the thermal energy requirements by solar systems}

\subsection{Reactor type and cycle layout}

High temperature heat is needed for the above solar-based hydrogen production technologies, although the operating temperatures depend on specific reactions and auxiliary. This means the solar irradiance must be concentrated to reach the required high temperature and the concentrated solar energy must be transferred to the reactant mixture. As the heat transfer must match the reactant residence time and heat quantity and quality, the heat transfer and relevant equipment design would be a major engineering challenge. In the above discussed solar-based fossil fuel technologies, if the hydrogen production reactor also serves as the solar irradiance concentrating receiver, an additional separate solar receiver may be saved. Figures 1 and 2 illustrate a typical design for the syngas production by reaction (1) in steam methane reforming reported by other investigators [16, 24]. The reactor could be a packed bed and the packing materials could be catalysts, porous absorber, and other solid materials serving as the heat absorber and reservoir [16]. Hydrogen is produced when the reactant gas mixture passes through the 
packing materials. In some other designs, packing materials may not be needed [24].

Considering the whole hydrogen production cycle rather than the single hydrogen production reaction, it can be observed that all hydrogen production cycles consist of a number of other auxiliary endothermic processes in addition to the chemical reaction, such as methane preheating, steam generation and superheating. It may not be a compact and economic design to arrange multiple solar irradiance receivers working as the preheating and superheating devices in the same solar thermal energy plant. Thus, arranging a separate solar receiver that can provide heat to all processes may be a viable option. In addition, a separate solar receiver also has the potential to store solar thermal energy for use at night and cloudy days. Particularly, if the solar thermal energy storage medium is in the form of liquid, e.g., molten salt, then it can be conveniently used for all heating purposes such as the reactant preheating and reaction enthalpy supply. A separate solar receiver also provides more flexibility for the location of the solar thermal energy plant that is not restricted by the chemical reactors for hydrogen production. Therefore, a separate solar receiver is recommended for the layout of the hydrogen production plant, wherein the processes are indirectly heated by the solar thermal energy. As a consequence, the concentrated sunlight in figures 1 and 2 can then be replaced by a heating jacket to allow a solar thermal working fluid to pass by and transfer heat the inside of the reactor.

Reactions (1), (2) and (5) and the processes in tables 1 and 2 indicate that the heat required by the processes can be categorized into three types: latent heat for steam generation, sensible heat for the preheating or superheating of steam and other reactants, and reaction enthalpy. As steam generation does not require a very high temperature, it makes the usage of solar thermal energy easier, because solar boiler technology has been very close to maturity and steam generation systems of different industrial scales have been operational [25-27].

For the preheating and superheating of the fluid reactants and intermediate products such as water, steam, and methane, a system of tube-and-shell heat exchangers could be utilized, as shown in figure 3. The solar thermal working fluid carries heat from a solar concentrating device to a tube-and-shell heat exchanger, and then transfers the heat to the fluid reactants or intermediate products. The heat exchanger 
could be of other types, for example, multi-tube or single shell heat exchangers [28-30].

Figure 4 illustrates a simplified version of the layout of the solar-based syngas production cycle utilizing indirect heating for reaction (1) and its auxiliary processes in steam methane reforming. In figure 4, the concentrated solar thermal energy is extracted by a solar thermal working fluid at a temperature of above $1,100^{\circ} \mathrm{C}$ that is higher than the temperature level of reaction (1). Then it flows through the syngas production reactor to supply heat to reaction (1). The reactor could be either the type of figure 1 or 2 . After the solar working fluid comes out of the reactor, its temperature is still higher than the reaction temperature, so heat can be transferred to the steam and methane superheating units, and then to the steam preheating and generation units. After the solar working fluid leaves the steam generator, it is pumped back to the solar irradiance concentrator. The produced syngas is at the reaction temperature, so the heat can be recovered for the preheating of both steam and methane. Note that there could be other layouts for the thermal energy transfer, which depend on the operating temperatures, available heat transfer equipment, and arrangement of heat recovery from the products of reaction (2). Since reaction (2) is an exothermic process that can be self-sustained after steam and methane are preheated to the reaction temperature, so the layout for reaction (2) is not illustrated in figure 4.

Regarding the methane dissociation for hydrogen and carbon black production, some investigators have performed studies on the solar-based reactors [17-21] and the reactor structures are similar to those shown in figures 1-3, either for direct or indirect heating purpose. An engineering challenge for methane dissociation is the removal and morphology control of the produced carbon black, so a tubular reactor and its modified version like a multi-tubular cavity-type reactor is preferred [31-33].

With respect to coal gasification, a major challenge of using solar thermal energy is the heat transfer in the solid reactant. Unlike a liquid, the solid carbon, e.g., charcoal, does not have a convection heat transfer mechanism and its thermal conductivity is insufficiently high. In comparison, steam methane reforming mainly deals with gases that have a better convection heat transfer rate than coal gasification. To overcome the heat transfer challenge in coal gasification, some investigators utilized molten salts to provide a direct contact mode in a thermal bath that could soak the charcoal for the gasification, and the 
molten salt is supplied from a separate solar concentrating plant [34]. The solar irradiance receiver serves as a packed bed and the structure is also similar to those illustrated in figures 1 and 2 [35-37], and the packing material was charcoal in the packed bed. A blackbody solar cavity-receiver / reactor were also tested for coal gasification [22, 23]. The extended applications of the solar powered coal gasification technology to other carbon-rich substances such as corn and biomass have also been investigated actively [35-38].

\subsection{Solar irradiance concentrator}

As discussed in the former sections, high temperature heat must be supplied in order to utilize solar thermal energy to satisfy the reaction enthalpy and superheating requirement for the operation of the conventional fossil fuel-based hydrogen production processes. Therefore, large amounts of solar irradiance must be concentrated to reach the temperature requirement. Currently, thermal oil-based solar thermal concentrators are operated below $450^{\circ} \mathrm{C}$ [39-42]. Solar troughs, lenses, parabolic dishes, heliostats, and reflection mirrors are typical devices for solar thermal energy concentration. A solar trough can concentrate more energy than a lens or a parabolic dish due to its larger concentrating area, but the temperature is usually below $500^{\circ} \mathrm{C}$ because of its relatively large surface area of tubular receiver [43]. So molten salt-based solar receivers or solar troughs in the temperature range of $450-500{ }^{\circ} \mathrm{C}$ are not able to provide sufficiently high temperatures to cover the temperature threshold of reactions (1), (5) and (7), though the range can well cover the temperature requirement for steam generation.

A solar tower that concentrates hundreds of megawatts of irradiance with heliostats or reflection mirrors can reach a temperature range of $500-1,000{ }^{\circ} \mathrm{C}$ [44-46], either utilizing a molten salt [34, 47-52] or gas as the working fluid to receive and transport the solar thermal energy [52-54]. This temperature range is capable of covering the minimum temperature requirements of reactions (1), (5), and (7), but cannot satisfy their upper levels. Significantly higher temperature furnaces for $2,000-3,900^{\circ} \mathrm{C}$ are also under active investigation including technologies of effectively reducing the reflection and heat losses [55-59]. These furnaces may satisfy the upper temperature levels of reactions (1), (5) and (7). 
One of the world's largest solar furnaces was constructed in 1970 at Odeillo, France. It consists of a $40 \mathrm{~m}$ high and $54 \mathrm{~m}$ wide paraboloidal concentrator parallel to its optical axis, and its focal length is 18 m. It can provide $1,000 \mathrm{~kW}$ of solar thermal energy in the temperature range of $2,950-3,825^{\circ} \mathrm{C}$ corresponding to the receiving diameter range of $40-2 \mathrm{~cm}$ [57]. Another 1,000 $\mathrm{kW}$ solar furnace was put into operation in Uzbekistan in 1987 , which can provide a temperature of $\sim 3,000^{\circ} \mathrm{C}$ on a focal plane with a diameter of $\sim 40 \mathrm{~cm}$ and rim angle of $\sim 70^{\circ}[58,59]$. These operational high temperature furnaces would provide a good basis for the future applications of solar thermal energy in hydrogen production.

\section{Conclusions}

This paper performed energy requirement analysis for several typical fossil fuel-based hydrogen production methods, i.e., steam methane reforming, methane dissociation, and coal gasification. Then it examined the feasibility and challenges of utilizing solar thermal energy to satisfy the heat requirements of steam generation, reactant preheating, and reaction enthalpy. The reduction of the $\mathrm{CO}_{2}$ emissions resulted from the usage of solar thermal energy was estimated. It was found that a reduction of $24 \%$ for steam methane reforming can be potentially achieved, and $8.5 \%$ for thermal dissociation of methane for the production of hydrogen and high value carbon black, and 31\% for the coal gasification.

This paper also examined the matching of the heat quality and quantity by solar thermal energy for different processes. It is concluded that steam generation by solar thermal energy for the supply of steam reactant to the steam methane reforming and coal gasification is particularly attractive due to the low temperature requirement and engineering maturity. Various solar-based reactors and heat transfer structures were also briefly discussed for different types of production cycles. It is concluded that steam methane reforming may have fewer engineering challenges than coal gasification because the steam methane reforming processes only experience single-phase changes, which facilitates the heat transfer and simplifies the equipment and loop design.

Acknowledgments: Support of this research from Atomic Energy of Canada Limited and the Ontario 
Research Excellence Fund is gratefully acknowledged.

\section{References :}

[1] Berger E. BMW hydrogen near zero emission vehicle development. BMW CleanEnergy. CARB ZEV. Technology Symposium. 2006; 6- 13. September 2006.

[2] Dalcor Consultants Ltd. 2005. Canadian Hydrogen Inventory. West Vancouver, BC, June, 2005.

[3] Freedonia Group. 2010. World Hydrogen Industry Study with Forecasts for 2013 \& 2018. Study\# 2605. February 2010.

[4] Yildiz B, Petri M C, Conzelmann G, Forsberg C. Configuration and technology implications of potential nuclear hydrogen system applications. Technical Report by Argonne National Laboratory, US: ANL-05/30. July 31, 2005.

[5] Forsberg CW 2002. Hydrogen, electricity, and nuclear power. Nuclear news. September 2002; 30-31.

[6] Naterer G, Gabriel K, Wang ZL. Thermochemical hydrogen production with a copper-chlorine cycle. I: oxygen release from copper oxychloride decomposition. International Journal of Hydrogen Energy. 2008; 33:5439 - 5450.

[7] Hauch A, Ebbesen SD, Jensen SH, Mogensen M. Highly efficient high temperature electrolysis. Journal of Materials Chemistry. 2008; 18: 2331-2340.

[8] Herring S. Laboratory-Scale High Temperature Electrolysis System. 2006 DOE Hydrogen, Fuel Cells \& Infrastructure Technologies Program Review Washington DC, May 17, 2006.

[9] Lewis MA, Taylor A. High temperature thermochemical processes. DOE Hydrogen Program, Annual Progress Report. Washington DC. 2006; $182-185$.

[10] Lewis MA. Update on the Cu-Cl cycle R\& D effort. Workshop of the ORF Hydrogen Project at AECL Chalk River Laboratories. Chalk River, Ontario, October 17, 2008; 25-33.

[11] Riccardi J, Massimo S, Fastelli I, Smitkova M. Modelling of Westinghouse and sulphur-iodine water splitting cycles for hydrogen production. International Journal of Energy and Environmental Engineering. 2011; 2: 49-62.

[12] Herdem MS. Combined coal gasification and alkaline water electrolyzer for hydrogen production. MASc Thesis, Department of Mechanical Engineering, University of Waterloo Canada. 2013.

[13] Abánades A. The challenge of hydrogen production for the transition to a CO2-free economy. Agronomy Research Biosystem Engineering Special Issue 1, 2012; 11-16.

[14] Möller S, Kaucic D, Sattler C. Hydrogen production by solar reforming of natural gas: A comparison study of two possible process configurations. Journal of Solar Energy Engineering. 2006; 128:16-23.

[15] Xue E., O’Keeffe M, Ross JRH. Water-gas shift conversion using a feed with a low steam to carbon monoxide ratio and containing sulphur. Catalysis Today. 1996; 30:107-118.

[16] Petrasch J, Steinfeld A. Dynamics of a solar thermochemical reactor for steam-reforming of methane. Chemical Engineering Science. 2007; 62: 4214 - 4228.

[17] Rodat S, Abanades S, Flamant G. Methane decarbonization in indirect heating solar reactors of 20 and $50 \mathrm{~kW}$ for a $\mathrm{CO}_{2}$-free production of hydrogen and carbon black. Journal of Solar Energy Engineering. 2011; 133: 031001-1 7.

[18] Wyss J, Martinek J, Kerins M, Dahl J K, Weimer A, Lewandowski A, Bingham C. Rapid solarthermal decarbonization of methane in a fluid-wall aerosol flow reactor - fundamentals and application. International Journal of Chemical Reactor Engineering. 2007; 5: A69 (1-28).

[19] D.P. Serrano, J.A. Botas, R. Guil-Lopez. $\mathrm{H}_{2}$ production from methane pyrolysis over commercial carbon catalysts: kinetic and deactivation study. International Journal of Hydrogen. 2009; 34: 4488 4494.

[20] Weimer AW, Dahl J, Buechler K. 2001. Thermal dissociation of mehane using a solar coupled aerosol reactor. Proceedings of the 2001 DOE Hydrogen Program Review. NREL/CP-570-30535.

[21] Dahl J, Buechler K, Finley R, Stanislaus T, Weimer A, Lewandowski A, Bingham C,Smeets A, Schneider A. Rapid solar-thermal dissociation of natural gas in an aerosol flow reactor. Proceedings of the 2002 U.S. DOE Hydrogen Program Review. NREL/CP-610-32405. 
[22] Zedtwitz P v, Petrasch J, Trommer D, Steinfeld A. Hydrogen production via the solar thermal decarbonization of fossil fuels. Solar Energy. 2006; 80: 1333-1337.

[23] Zedtwitz P v, Steinfeld A.. The solar thermal gasification of coal - energy conversion efficiency and CO2 mitigation potential. Energy. 2003; 28: 441-456.

[24] Maegami Y, Iguchi F, Yugami H. Efficient solar methane reforming using spectrally controlled thermal radiation produced by concentrated solar radiation. Proceedings of the ASME 5th International Conference on Energy Sustainability (ES2011). Paper No. ES2011-54612. August 7-10, 2011, Washington, DC, USA.

[25] Eck M, Steinmann WD, Direct steam generation in parabolic troughs. Proceedings of Solar Forum 2001: Solar Energy: The Power to Choose. Washington D.C., US, April 21-25, 2001.

[26] Menghani PD, Udawant RR, Funde AM, Dingare SV. Low pressure steam generation by solar energy with Fresnel lens: a review. Second International Conference on Emerging Trends in Engineering \& Technology (ICETET-09). Nagpur, Maharashtra, India. December 16-18, 2009.

[27] Dascomb J. Low-cost concentrating solar collector for steam generation. MSc Thesis, Florida State University. FAMU-FSU College Engineering. Spring Semester, 2009.

[28] Böhmer M, Langnickel U, Sanchez M. Solar steam reforming of methane. Solar Energy Materials. 1991; 24: 441-448.

[29] De Falco M, Piemonte V. Solar enriched methane production: Assessment of plant potentialities and applications. Applied Technologies and Innovations. 2010; 1: 1-8.

[30] Giaconia A, Labach I, Caputo G, Sau S. Experimental and theoretical studies of solar steam reforming assisted by molten salts. 18th World Hydrogen Energy Conference 2010 - WHEC 2010. Parallel Sessions Book 3: Hydrogen Production Technologies - Part 2. Proceedings of the WHEC. May 16.-21. 2010, Essen, Germany.

[31] Rodat S, Abanades S, Flamant G.. High-temperature solar methane dissociation in a multitubular cavity-type reactor in the temperature range 1823-2073 K. Energy Fuels. 2009; 23: 2666-2674.

[32] Rodat S, Abanades S, Grivei E, Patrianakos G, Zygogianni A, Konstandopoulos AG, Flamant G. Characterisation of carbon blacks produced by solar thermal dissociation of methane. Carbon. 2011; 49: $3084-3091$.

[33]Hirsch D, Epstein M, Steinfeld A. The solar thermal decarbonization of natural gas. International Journal of Hydrogen Energy. 2001; 26: 1023-1033.

[34] Matsunami J, Yoshida S, Oku Y. Coal gasification with $\mathrm{CO}_{2}$ in molten salt for solar thermal / chemical energy conversion. Energy. 2000; 25: 71-79.

[35] Piatkowski N, Steinfeld A. Solar-Driven Coal Gasification in a Thermally Irradiated Packed-Bed Reactor. Energy \& Fuels. 2008; 22: 2043-2052.

[36] Piatkowski N, Wieckert C, Steinfeld A. 2008. Experimental investigation of a packed-bed solar reactor for the steam-gasification of biomass charcoal. ES2008-54118. Proceedings of ES2008 Energy Sustainability. August 10-14, 2008, Jacksonville, Florida, USA.

[37] Piatkowski N, Wieckert C, Weimer AW. Solar-driven gasification of carbonaceous feedstock - a review. Energy and Environmental Science. 2011; 4: 73-82.

[38] Perkins CM, Woodruff B, Andrews L. Synthesis gas production by rapid solar thermal gasification of corn stover. NREL/CD-550-42709. 14th Biennial CSP SolarPACES (Solar Power and Chemical Energy Systems) Symposium, 4-7 March 2008, Las Vegas, Nevada .

[39]Moens L, Blake DM, Rudnicki DL, Hale MJ. Advanced thermal storage fluids for solar parabolic trough systems. Journal of Solar Energy Engineering. 2003; 125: 112-116.

[40] Moens L, Blake DM. Advanced heat transfer and thermal storage fluids. 2004 DOE Solar Energy Technologies Program Review Meeting. October 25-28, 2004. Denver, Colorado.

[41] Eck M, Hennecke K. 2007. Heat transfer fluids for future parabolic trough solar thermal power plants. Proceedings of ISES World Congress 2007 (Vol. I - Vol. V). Editors: Goswami DY, Zhao Y. Publisher: Springer. 2009; 5: 1806-1812.

[42] Wu B, Reddy RG. Novel ionic liquid thermal storage for solar thermal electric power systems. Proceedings of Solar Forum 2001. Solar Energy: The Power to Choose. April 21-25, 2001, 
Washington, DC.

[43] Herrmann U, Kelly B, Price H. Two-tank molten salt storage for parabolic trough solar power plants. Energy. 2004; 29: 883-893.

[44] Schramek P, Mills DR, Stein W. Design of the heliostat field of the CSIRO solar tower. Journal of Solar Energy Engineering. 2009;131: 024505-1 024505-6.

[45] Spelling J. Thermo-economic optimisation of solar tower thermal power plants. 22nd International Conference on Efficiency, Cost, Optimisation, Simulation and Environmental Impact of Energy Systems (ECOS 2009). Foz do Iguaçú - BRAZIL. August 31 - September 3, 2009.

[46] Dersch J, Schwarzbözl P, Richert T. Annual yield analysis of solar tower power plants with GREENIUS. Journal of Solar Energy Engineering. 2011; 133: 031017-1 031017-9.

[47] Forsberg CW, Peterson PF, Zhao H. High-temperature liquid-fluoride-salt closed-Brayton-cycle solar power towers. Journal of Solar Energy Engineering. 2007; 129: 141-146.

[48] Dunn RI, Hearps PJ, Wright MN. Molten-salt power towers: newly commercial concentrating solar storage. Proceedings of the IEEE. 2012; 100: 504-515.

[49] Moore R, Vernon M, Ho CK, Siegel NP, Kolb GJ. 2010. Design considerations for concentrating solar power tower systems employing molten salt. Sandia Report SAND2010-6978. Available to the public from U.S. Department of Commerce National Technical Information Service. 5285 Port Royal Rd. Springfield, VA 22161. Printed September 2010.

[50] Khan MA, Chen Y, Boehm R. 2004. Process analysis and simulation of the solar thermo-chemical hydrogen generation. ASME 2004 International Mechanical Engineering Congress and Exposition (IMECE2004). Paper no. IMECE2004-59647. pp. 195-202. November 13 - 19, 2004, Anaheim, California, USA.

[51] Martín JC. Solar Tres - First commercial molten salt central receiver. NREL CSP Technology Workshop. Denver, US. March 7, 2007.

[52] Schwarzbözl P, Buck R, Sugarmen C, Ring A, Marcos Crespo MJ, Altwegg P, Enrile J. Solar gas turbine systems: design, cost and perspectives. Solar Energy. 2006; 80: 1231-1240.

[53] Ahlbrink N, Belhomme B, Pitz-Paal R. Modeling and simulation of a solar tower power plant with open volumetric air receiver. Proceedings 7th Modelica Conference, Como, Italy, Sep. 20-22, 2009; 685-693.

[54] Göttsche J, Hoffschmidt B, Schmitz S, Ifland D, Teufel E, Hoffschmidt B, Schmitz S, Rebholz C, Sauerborn M. Solar concentrating systems using small mirror arrays. Journal of Solar Energy Engineering. 2010; 132: 011003-1 011003-4.

[55] Haueter P, Seitz T, Steinfeld A. A new high-flux solar furnace for high-temperature thermochemical research. Journal of Solar Energy engineering, 1999; 121: 77-80.

[56] Riveros-Rosas D, Herrera-Vázquez J, Pérez-Rábago CA, Arancibia-Bulnes CA, Vázquez-Montiel S, Sánchez-González M, Granados-Agustín F, Jaramillo OA, Estrada CA. Optical design of a high radiative flux solar furnace for Mexico. Solar Energy. 2010; 84: 792-800.

[57] Garg HP, Prakash J. Solar Energy: Fundamentals and Applications. Tata McGraw-Hill Publishing Company Limited. ISBN 0-07-463631-6, first edition, 2000; pp310-311.

[58] Payziyev Sh, Bakhramov S, Klichev Sh, Kasimov A, Riskiev T, Abdurakhmanov A, Fazilov A. Big Solar Furnace as pumping source for high power lasers. Proceedings of SPIE. 2008; 6871: 68712E$1 \sim 8$.

[59] Abdurakhmanov AA, Zainutdinova Kh K, Mamatkosimov MA, Paizullakhanov MS, Saragoza G. Solar technologies in Uzbekistan: state, priorities, and perspectives of development. Applied Solar Energy. 2012; 48: 84-91. 
Tables:

Table 1: Energy equivalent of extra $\mathrm{CO}_{2}$ emissions in SMR based on a heat balance

\begin{tabular}{|c|c|c|c|}
\hline Process & $\begin{array}{c}\text { Enthalpy change }^{(\mathrm{a})} \text {, } \\
\mathbf{k J} / \mathbf{m o l}\end{array}$ & Mode of energy transfer & $\mathrm{T},{ }^{\circ} \mathrm{C}$ \\
\hline $\begin{array}{c}\mathrm{CH}_{4}(\mathrm{~g})+\mathrm{H}_{2} \mathrm{O}(\mathrm{g})=\mathrm{CO}(\mathrm{g})+ \\
3 \mathrm{H}_{2}(\mathrm{~g})\end{array}$ & 206.25 & Reaction enthalpy & 900 \\
\hline $\mathrm{CO}(\mathrm{g})+\mathrm{H}_{2} \mathrm{O}(\mathrm{g})=\mathrm{CO}_{2}(\mathrm{~g})+\mathrm{H}_{2}(\mathrm{~g})$ & -41.03 & reaction enthalpy & 400 \\
\hline $\mathrm{CH}_{4}(20 \mathrm{C})=\mathrm{CH}_{4}(900 \mathrm{C})$ & 31.26 & preheating & $20 \rightarrow 900$ \\
\hline $\mathrm{H}_{2} \mathrm{O}(\mathrm{l}, 20 \mathrm{C})=\mathrm{H}_{2} \mathrm{O}(\mathrm{g}, 900 \mathrm{C})$ & 66.27 & preheating and evaporation & $20 \rightarrow 900$ \\
\hline $\mathrm{H}_{2} \mathrm{O}(\mathrm{l}, 20 \mathrm{C})=\mathrm{H}_{2} \mathrm{O}(\mathrm{g}, 400 \mathrm{C})$ & 54.54 & preheating and evaporation & $20 \rightarrow 400$ \\
\hline $\mathrm{CO}(\mathrm{g}, 900 \mathrm{C})=\mathrm{CO}(\mathrm{g}, 400 \mathrm{C})$ & -14.28 & cooling & $900 \rightarrow 400$ \\
\hline $3 \mathrm{H}_{2}(\mathrm{~g}, 900 \mathrm{C})=3 \mathrm{H}_{2}(\mathrm{~g}, 20 \mathrm{C})$ & -25.20 & cooling & $900 \rightarrow 20$ \\
\hline $\mathrm{H}_{2}(\mathrm{~g}, 400 \mathrm{C})=\mathrm{H}_{2}(\mathrm{~g}, 20 \mathrm{C})$ & -10.88 & cooling & $400 \rightarrow 20$ \\
\hline $\mathrm{CO}_{2}(\mathrm{~g}, 400 \mathrm{C})=\mathrm{CO}_{2}(\mathrm{~g}, 20 \mathrm{C})$ & -14.11 & cooling & $400 \rightarrow 20$ \\
\hline Sum: & 252.81 & & \\
\hline $\begin{array}{l}\text { Additional methane to be } \\
\text { combusted for the heat supply (b) }\end{array}$ & \multicolumn{2}{|c|}{$252.81 / 802.31 \times 100 \%=31.5 \%$} & \\
\hline Potential $\mathrm{CO}_{2}$ reduction & \multicolumn{2}{|c|}{$0.315 /(1+0.315) \times 100 \%=23.9 \%$} & \\
\hline \multicolumn{4}{|c|}{$\begin{array}{l}\text { (a) A negative value means exothermic, i.e., heat is released from the process, while a positive value } \\
\text { means endothermic, i.e., heat is required by the process. } \\
\text { (b) The combustion heat of methane is } 802.31 \mathrm{~kJ} / \mathrm{mol} \text { with the following complete reaction: } \mathrm{CH}_{4}+ \\
2 \mathrm{O}_{2}=\mathrm{CO}_{2}+2 \mathrm{H}_{2} \mathrm{O}(\mathrm{g})\end{array}$} \\
\hline
\end{tabular}


Table 2: Energy equivalent of extra $\mathrm{CO}_{2}$ emissions in methane decarbonization

\begin{tabular}{|c|c|c|c|}
\hline Process & $\begin{array}{c}\text { Enthalpy change }^{(\mathrm{a})} \text {, } \\
\mathbf{k J} / \mathbf{m o l}\end{array}$ & Mode of energy transfer & $\mathrm{T},{ }^{\circ} \mathrm{C}$ \\
\hline $\mathrm{CH}_{4}(\mathrm{~g})=\mathrm{C}(\mathrm{s})+2 \mathrm{H}_{2}(\mathrm{~g})$ & 74.9 & Reaction enthalpy & 1,900 \\
\hline $\mathrm{CH}_{4}(20 \mathrm{C})=\mathrm{CH}_{4}(1,900 \mathrm{C})$ & 66.8 & Preheating & $20 \rightarrow 1,900$ \\
\hline $2 \mathrm{H}_{2}(\mathrm{~g}, 1,900 \mathrm{C})=2 \mathrm{H}_{2}(\mathrm{~g}, 20 \mathrm{C})$ & -107.7 & cooling & $1,900 \rightarrow 20$ \\
\hline$C(s, 1,900 C)=C(s, 20 C)$ & -16.0 & cooling & $1,900 \rightarrow 20$ \\
\hline Sum for all temperatures: & 18.0 & & \\
\hline Sum at $1,900 \mathrm{C}$ : & 74.9 & & \\
\hline $\begin{array}{l}\text { Additional methane to be } \\
\text { combusted for the heat supply }{ }^{\text {(b) }}\end{array}$ & \multicolumn{2}{|c|}{$74.9 / 802.3 \times 100 \%=9.3 \%$} & \\
\hline Potential $\mathrm{CO}_{2}$ reduction & \multicolumn{2}{|c|}{$0.093 /(1+0.093) \times 100 \%=8.5 \%$} & \\
\hline \multicolumn{4}{|c|}{$\begin{array}{l}\text { (a) A negative value means exothermic, i.e., heat is released from the process, while a positive value } \\
\text { means endothermic, i.e., heat is required by the process. } \\
\text { (b) The combustion heat of methane is } 802.3 \mathrm{~kJ} / \mathrm{mol} \text { with the following complete reaction: } \mathrm{CH}_{4}+2 \mathrm{O}_{2} \\
=\mathrm{CO}_{2}+2 \mathrm{H}_{2} \mathrm{O}(\mathrm{g})\end{array}$} \\
\hline
\end{tabular}




\section{List of figure captions:}

Figure 1. Typical steam methane reformer serving as a solar irradiance receiver

Figure 2. Tubular steam methane reformer serving as a solar irradiance receiver.

Figure 3. Shell and tube type steam methane reformer

Figure 4. Layout of a solar-based syngas production cycle utilizing indirect heating 


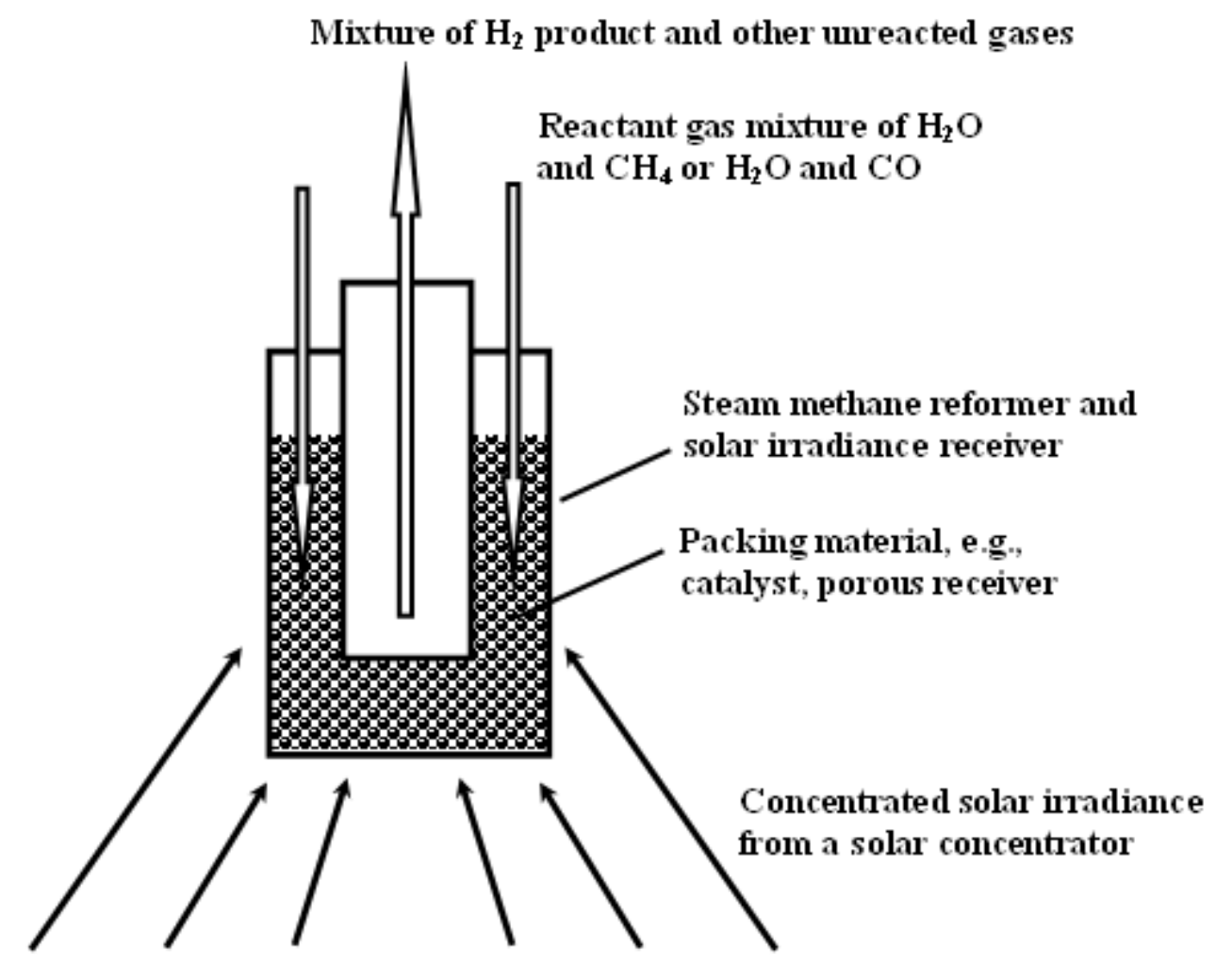

Figure 1. 
Tubular steam methane reformer and solar irradiance receiver
Packing material, e.g., catalyst, porous receiver
Reactant gas mixture of $\mathrm{H}_{2} \mathrm{O}$ and $\mathrm{CH}_{4}$ or $\mathrm{H}_{2} \mathrm{O}$ and $\mathrm{CO}$

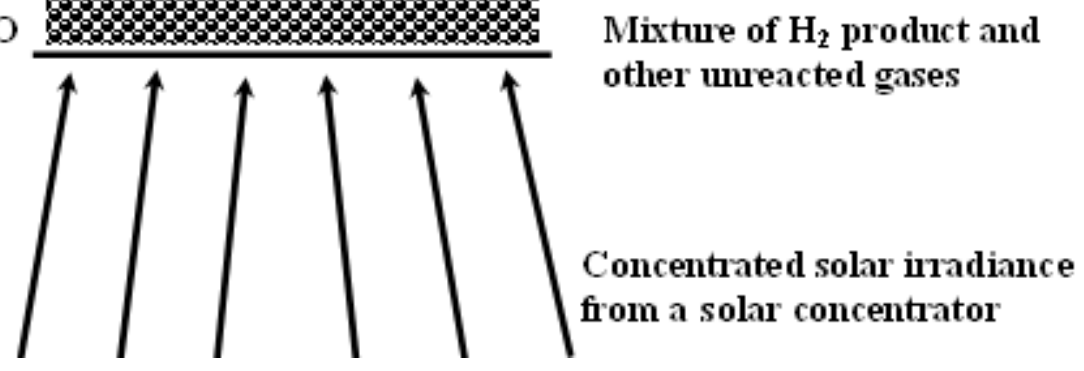

Figure 2. 
Low temperature working fluid
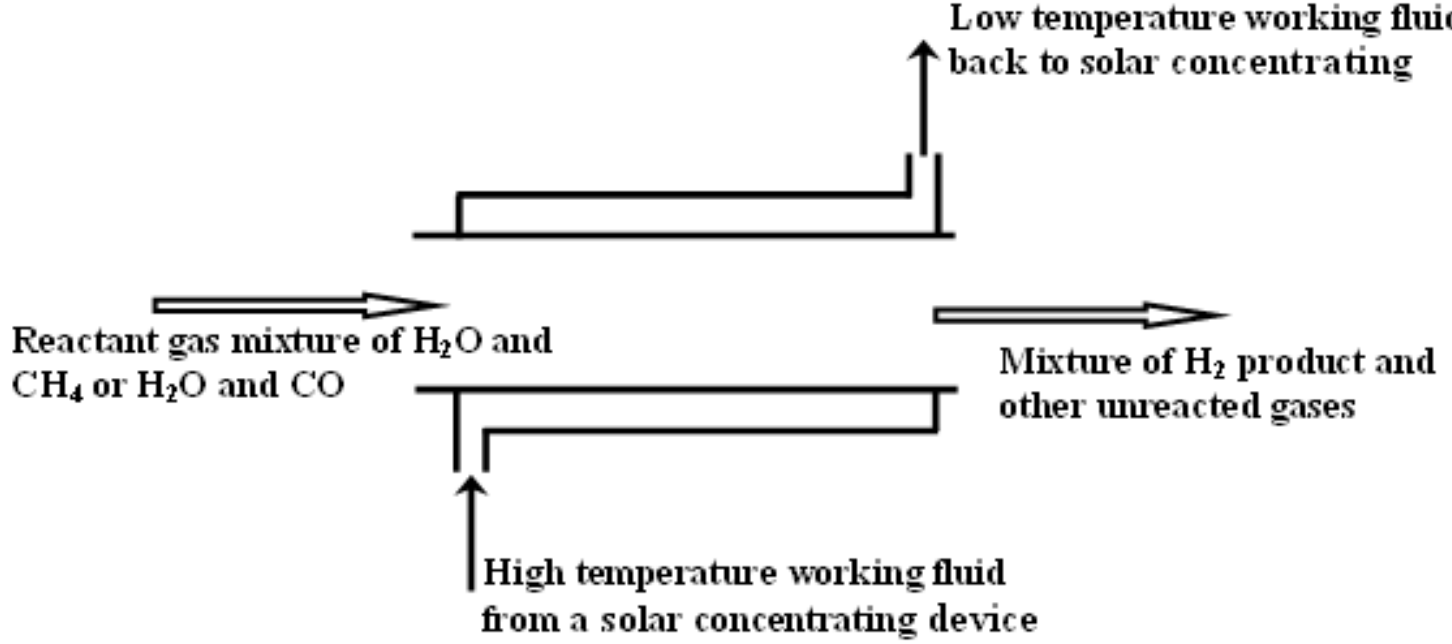

Figure 3. 


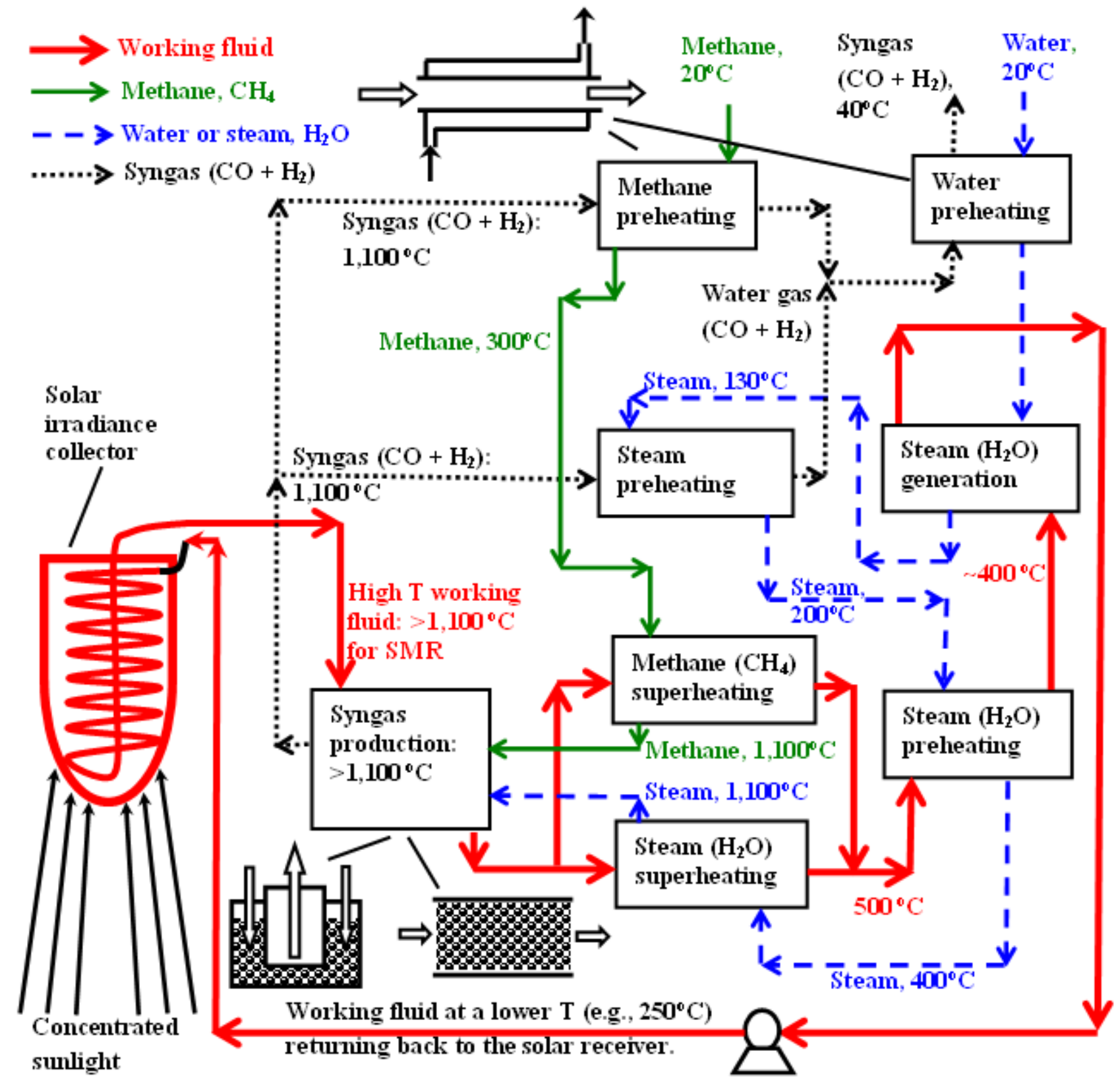

Figure 4. 